\section{STATMAT}

(Jurnal Statistika dan Matematika)

\title{
PREDIKSI PENJUALAN SERAGAM SEKOLAH DENGAN MENGGUNAKAN METODE ARIMA (Autoreggressive Integrated Moving Average) \\ ( Studi Kasus : Koperasi Karyawan Yayasan Umara Al-Zahra Indonesia)
}

\author{
Hendro Waryanto ${ }^{1}$ dan Dwi Aprisa Wanti ${ }^{2}$ \\ ${ }^{1}$ Program Studi Matematika, FMIPA - UNPAM \\ 1dosen0052@unpam.ac.id
}

\begin{abstract}
ABSTRAK
Tujuan dari penelitian yaitu mengetahui metode ARIMA (Autoreggressive Integrated Moving Average) dapat digunakan untuk meramalkan penjualan seragam sekolah Kopkar Al-Zahra Indonesia. Mengetahui bentuk persamaan model ARIMA yang tepat dalam meramalkan penjualan seragam sekolah Kopkar Al-Zahra Indonesia. Mengetahui jumlah penjualan seragam sekolah pada bulan Agustus, September, dan Oktober, November, Desember tahun 2018. Metode yang digunkaan yaitu metode perancangan dan metode kepustakaan. Metode ARIMA (Autoreggressive Integrated Moving Average) dapat digunakan untuk meramalkan penjualan seragam sekolah Kopkar Al-Zahra Indonesia karena data penjualan seragam sekolah tersebut membentuk data musiman, sehingga metode yang tepat adalah metode ARIMA. Bentuk persamaan dengan model ARIMA $(1,1,1)$ sebagai berikut:$$
X_{t}=19,876+e_{t}-(-0,645) e_{t-1}+X_{t-1}+(-0,369) X_{t-1}-(-0,369) X_{t-2}
$$

Hasil prediksi jumlah penjualan seragam sekolah Kopkar Sekolah Al-Zahra Indonesia untuk 5 periode berikutnya adalah pada bulan Agustus 2018 sebanyak 700,3 buah seragam, bulan September 2018 sebanyak 708,6 buah seragam, bulan Oktober 2018 sebanyak 732,7 buah seragam, bulan November sebanyak 751 buah seragam, dan bulan Desember 2018 sebanyak 771,5 buah seragam.

Kata Kunci : ARIMA, model, prediksi
\end{abstract}

\section{PENDAHULUAN}

\subsection{Latar Belakang Masalah}

Koperasi adalah salah satu bentuk usaha berbadan hukum yang berdiri di Indonesia. Koperasi indonesia adalah badan usaha yang beranggotakan orangorang, seseorang, atau badan hukum koperasi dengan melandaskan kegiatannya berdasarkan prinsip koperasi, sekaligus sebagai gerakan ekonomi rakyat yang berdasarkan asas kekeluargaan.

Koperasi berperan postif dalam pelaksanaan pembangunan nasional di Indonesia, baik secara langsung maupun tidak langsung. Hal ini sesuai dengan tujuan koperasi, khususnya untuk memajukan kesejahteraan anggotanya dan masyarakat pada umumnya. Sedangkan sekolah merupakan lembaga tempat berlangsungnya proses belajar mengajar antara guru dan siswa. Maka, koperasi 
(Jurnal Statistika dan Matematika)

sekolah merupakan koperasi yang didirikan di ligkungan sekolah, dan beranggotakan seluruh warga sekolah, seperti guru, pegawai, maupun siswa dengan tanggung jawab dipegang oleh kepala sekolah. Mereka dapat memenuhi kebutuhan ekonominya melalui kegiatan koperasi yang diusahakan secara bersama.

Keberadaan koperasi sekolah merupakan wahana belajar seluruh warga sekolah khususnya bagi siswa untuk mengenal, mengetahui, memeahami, dan kemudian mengimplementasikan pengetahuannya dalam kehidupan bermasyarakat. Diharapkan juga koperasi sekolah dapat merangsang tumbuhnya minat usaha kecil dan kreatif, mengembangkan kemampuan berorganisasi, mendorong kebiasaan berinovasi, belajar menyelesaikan masalah bersama, mengasah mental bertanggung jawab, dan lain sebagainya.

Koperasi Karyawan Al-Zahra Indonesia merupakan sebuah koperasi yang kebanyakan anggotanya adalah guru, staff dan pegawai dilingkup Yayasan Umara. Kopeasi tersebut menangani jenis usaha yang bergerak pada sektor perlengkapan dan simpan pinjam. Pada sektor perlengkapan menyediakan barang-barang keperluan sekolah, seperti : alat tulis, buku pelajaran serta semua perlengkapan sekolah dan aneka kebutuhan sehari-hari yang dibutuhkan dalam sekala kecil. Sektor simpan pinjam memberikan jasa simpan pinjam yang diperuntukan pada anggota koperasi.

Dikarenakan adanya lonjakan penjualan seragam di bulan-bulan tertentu, maka penjualan seragam sekolah menjadi tidak dapat diprediksi dengan baik. Hal ini biasanya disebabkan oleh pergantian tahun ajaran baru, pergantian semester dan pergantian jenjang pendidikan yang dialami oleh para siswa. Hal ini yang menyebabkan seringnya Kopkar Al-Zahra Indonesia mengalami kehabisan stok.

Dalam penelitian ini penulis mencoba menganalisa penjualan seragam di Koperasi Karywan Al-Zahra Indonesia menggunakan metode ARIMA ( Autoreggressive Integrated Moving Average ) dengan mengidentifikasi data yang digunakan untuk meramalkan jumlah penjualan seragam sekolah pada waktu yang akan datang sehingga mendapatkan nilai kesalahan yang terkecil.

Berdasarkan uraian latar belakang di atas maka penulis memilh judul "PREDIKSI PENJUALAN SERAGAM SEKOLAH KOPKAR AL-AZHRA INDONESIA DENGAN MENGGUNAKAN METODE ARIMA (Autoreggressive Integrated Moving Average)"

\section{METODOLOGI PENELITIAN}

\subsection{BOX JENKINS (ARIMA)}

\subsubsection{ARIMA (Autoregressive Integrated Moving Average)}

ARIMA sering juga disebut metode runtun waktu Box-Jenkins. ARIMA sngat baik ketepatannya untuk peramalan jangka pendek, sedangkan untuk 
(Jurnal Statistika dan Matematika)

peramalan jangka panjang ketepatan peramalannya kurang baik. Biasanya akan cenderung flat (mendatar/konstan) untuk periode yang cukup panjang. Model Autoregressive Integrated Moving Average (ARIMA) adalah model yang secara penuh mengabaikan independen variabel dalam membuat permalan. ARIMA menggunakan nilai massa lalu dan sekarang dari variabel dependen untuk menghasilkan peramalan jangka pendek yang akurat. ARIMA cocok jika observasi dari deret waktu (time series) secara statistik berhubungan satu sama lain (dependent).

\subsubsection{Satsionritas dan Nonstasioneritas}

Hal yang perlu diperhatikan adalah bahwa kebanyakan deret berkala bersifat nonstasioner dan bahwa aspek-aspek AR dan MA dari model ARIMA hanya berkenaan dengan deret berkala yang stasioner. Stasioneritas berarti tidak terdapat pertumbuhan atau penurunn pada data. Data secar kasarnya harus horisontal sepanjang sumbu waktu. Dengan kata lain, fluktuasi data berada di sekitar suatu nilai rata-rata yang konstan, tergantung pada waktu dan varians dari fluktuasi tersebut pada pokoknya tetap konstan setiap waktu. Suatu deret waktu yang tidak stasioner harus diiunah menjadi data stasioner dengan melakuakan diffrencing. Yang dimaksud dengan diffrencing adalah menghitung perubahan atau selisih nilai observasi. Nilai selisih yang diperoleh dicek lagi apakah stasionr atau tidak. Jika belum stasioner maka dilakukan diffrencing lagi. Jika varians tidak stasioner, maka dilakukan transformasi logaritma.

\subsubsection{Klasifikasi model ARIMA}

Model Box-Jenkins (ARIMA) dibagi kedalam 3 kelompok yaitu: model Autoregresivve (AR), Moving Average (MA), dan model campuran ARIMA (Autoregressive Integrated Moving Average) yang mempunyai karakteristik dari dua model yaitu:

1) Model Autoregresivve (AR)

Bentuk umum model Autoregresivve (AR) dengan ordo $\mathrm{p}(\mathrm{AR}(\mathrm{p}))$ atau model ARIMA $(\mathrm{p}, 0,0)$ dinyatakan sebagai berikut:

$$
X_{t}=\mu^{\prime}+\emptyset_{1} X_{t-1}+\emptyset_{2} X_{t-2}+\cdots+\emptyset_{p} X_{t-p}+e_{t}
$$

Dimana:

$\mu^{\prime}=$ suatu konstanta

$\emptyset_{p}=$ parameter Autoregresivve

$e_{t}=$ nilai kesalahan pada saat $\mathrm{t}$

2) Moving Average (MA)

Bentuk umum model Moving Average (MA) ordo q (MA(q)) atau $\operatorname{ARIMA}(0,0, q)$ dinyatakan sebagai berikut: 
Dimana:

$$
X_{t}=\mu+e_{t}-\theta_{1} e_{t-1}-\theta_{2} e_{t-2}-\cdots-\theta_{p} e_{t-k}
$$

$\mu^{\prime}=$ suatu konstanta

$\theta_{1}$ dan $\theta_{q}$ adalah parameter-parameter Moving Average

$e_{t-k}=$ nilai kesalahan pada saat $\mathrm{t}-\mathrm{k}$

3) Model Campuran

a. Proses ARMA

Model umum untuk campuran proses AR(1) murni dan MA(1) murni, misal ARIMA $(1,0,1)$ dinyatakan sebagai berikut:

$$
X_{t}=\mu^{\prime}+\emptyset_{1} X_{t-1}+e_{t}-\theta_{1} e_{t-1}
$$

Atau

$$
\left(1-\emptyset_{1} B\right) X_{t}=\mu^{\prime}+\left(1-\emptyset_{1} B\right) e_{t}
$$

Dimana:

$$
\begin{aligned}
& \left(1-\emptyset_{1} B\right)=\operatorname{AR}(1) \\
& \left(1-\emptyset_{1} B\right)=\operatorname{MA}(1)
\end{aligned}
$$

b. Proses ARIMA

Apabila non stasioneritas ditambahkan pada campuran proses ARMA, maka model umum ARIMA (p,d,q) terpenuhi. Persamaan untuk kasus sederhana ARIMA $(1,1,1)$ adalah sebagai berikut :

$$
(1-B)\left(1-\emptyset_{1} B\right) X_{t}=\mu^{\prime}+\left(1-\emptyset_{1} B\right) e_{t}
$$

Dimana :

$$
\begin{aligned}
& (1-B): \text { Pembedaan Pertama } \\
& \left(1-\emptyset_{1} B\right)=\text { AR }(1) \\
& \left(1-\emptyset_{1} B\right)=\text { MA }(1)
\end{aligned}
$$

\subsubsection{Musiman dan Model ARIMA}

Musiman didefinisikan sebagai pola yang berulang-ulang dalam selang waktu yang tetap. Untuk data yng stasioner, faktor musiman dapat di tentukan dengan mengidentifikasi koefisien autokorelasi pada dua atau tiga time-lag yang berbeda nyata dari nol. Autokorelasi yang secara signifikan berbeda dari nol menyatakan adanya suatu pla dalam data. Untuk mengenli adanya faktor musiman. Seseorang harus melihat pada autokorelasi yang tinggi. Untuk menangani musiman, notasi umum yang singkat adalah:

$$
\begin{aligned}
& \text { ARIMA }(p, d, q)(P, D, Q)^{S} \\
& \text { Dimana : } \\
& \begin{array}{ll}
(p, d, q) \quad=\text { bagian yang tidak musiman dari model } \\
(P, D, Q) & =\text { bagian musiman dari model } \\
& =\text { jumlah periode per musim }
\end{array}
\end{aligned}
$$




\section{STATMAT}

(Jurnal Statistika dan Matematika)

\subsubsection{Tahapan-tahapan pembuatan model ARIMA}

1) Identifikasi Model Tentatif (sementara)

2) Pendugaan parameter

3) Cek diagnostic

4) Forecasting (peramalan)

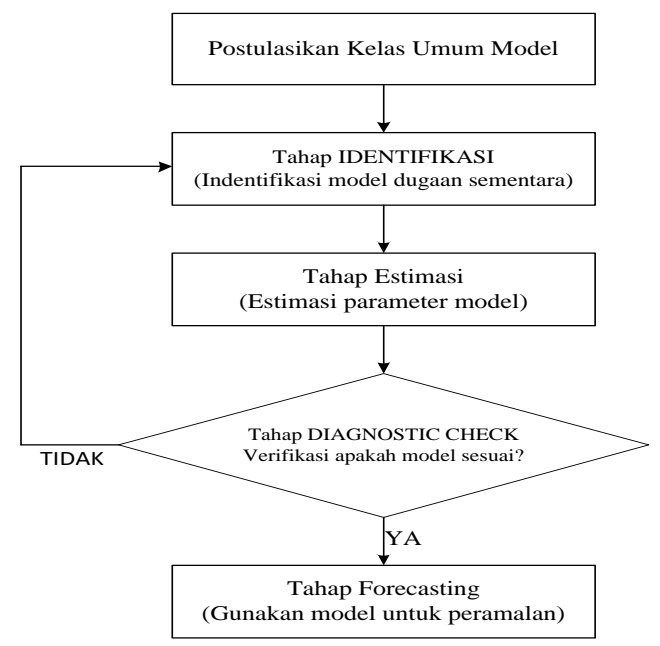

Gambar 1. Flowchart Autoregressive Integrated Moving Average (ARIMA)

\subsubsection{Identifikasi}

Proses identifikasi dari model musiman tergantung pada alat-alat statistik berupa autokorelasi dan parsial autokorelasi, serta pengetahuan terhadap sistem (atau proses) yang dipelajari.

\subsubsection{Pendugaan Parameter}

Ada dua cara yang mendasar untuk mendapatkan parameter-parameter tersebut:

a. Dengan cara mencoba-coba (Trial And Error), menguji beberapa nilai yang berbeda dn memilih stu nilai tersebut (atau sekumpulan nilai, apabila terdapat lebih dari satu parameter yang akan ditaksir) yang akan meminimumkan jumlah kuadrat nilai sisa (sum of squad residual).

b. Perbaikan secara iteratif, memilih taksiran awal dan kemudian membiarkan program komputer memperhalus penaksiran tersebut secara iteratif.

\subsubsection{Cek Diagnostic}

Setelah menduga parameter, langkas selanjutnya adlah menguji model apakah modelnya sudah baik digunakan.

1. Pengujian masing-masing parameter model secara parsial (m-test).

2. Pengujian model secara keseluruhan (Overall F test). 
(Jurnal Statistika dan Matematika)

Model dikatakan baik jika niklai error bersifat random, artinya sudah tidak mempunyai pola tertentu lagi. Dengan kata lain model yang diperoleh dapat menangkap dengan baik pola data yang ada. Untuk melihat kerandoman nilai error dilakukan pengujian terhadap nilai koefisien autokorelasi dari error, dengan menggunakan salah satu dari dua statistik berikut:

1) Uji Q-Box dan Pierce :

$$
Q=n^{\prime} \sum_{k=1}^{m} r_{k^{2}}
$$

2) Uji Ljung-Box :

$$
Q=n^{\prime}\left(n^{\prime}+2\right) \sum_{k=1}^{m} \frac{r_{k^{2}}}{\left(n^{\prime}-k\right)}
$$

Menyebar secara Khi Kuadrat $\left(\mathrm{X}^{2}\right)$ dengan derajat bebas $(\mathrm{db})=(\mathrm{k}-\mathrm{p}-\mathrm{q}-\mathrm{P}-\mathrm{Q})$

Dimana :

$\mathrm{n}^{\prime}=\mathrm{n}-(\mathrm{d}+\mathrm{SD})$

$\mathrm{d} \quad=$ ordo pembedaan bukan faktor musiman

$\mathrm{m}=$ lag waktu musiman

$r_{k}=$ auto korelasi untuk time-lag $1,2,3,4, \ldots \ldots, \mathrm{k}$

Kriteria pengujian:

Jika $\mathrm{Q} \leq\left(\mathrm{X}^{2}\right) \alpha \mathrm{db}$, berarti: nlai error bersifat random (model dapat diterima)

Jika $\mathrm{Q}>\left(\mathrm{X}^{2}\right) \alpha \mathrm{db}$, berarti: nlai error tidak bersifat random (model tidak dapat diterima)

Untuk menentukan model yang terbaik dapat digunakan standard error estimate berikut:

$$
S=\left[\frac{S E E}{n-n p}\right]^{\frac{1}{2}}=\left[\frac{\sum_{t=1}^{m}\left(Y_{t}-\hat{Y}_{t}^{2}\right)}{n-n p}\right]^{\frac{1}{2}}
$$

Dimana:

$Y_{t}=$ nilai sebenarnya pada waktu ke-t

$\hat{Y}_{t}=$ nilai dugaan pada waktu ke-t

Model terbaik adalah model yang memiliki nilai standard error estimate (S) yang paling kecil. Selain nilai standard error estimate, nilai rata-rata presentasi kesalahan peramalan (MAPE) dapat juga digunakan sebagai bahan petimbangan dalam menentukan model yang terbaik yaitu: diterima

$$
M A P E=\frac{\sum_{t=1}^{r}\left|\frac{Y_{t}-\hat{Y}_{t}}{Y_{t}}\right|}{T} \times 100 \%
$$




\section{STATMAT}

(Jurnal Statistika dan Matematika)

Dimana:

$\mathrm{T}=$ banyaknya periode peramalan/dugaan .

\subsubsection{Peramalan Dengan Model ARIMA}

Setelah model terbaik diperoleh, selanjutnya peramalan dapat dilakuakan. Dalam berbagai kasus, peramalan degan metode ini lebih dipercaya daripada permalan yang dilakukan dengan model ekonometri tradisional. Namun, hal ini tentu saja perlu dipelajari lebih lanjut oleh para peneliti yang tertarik menggunakan metode serupa. Berdasarkan ciri yang dimilikinya, model runtun waktu seperti ini lebih cocok untuk peramalan dengan jangkauan sangangat pendek, sementara model struktural lebih cocok untuk peramalan dengan jangkauan panjang (Mulyono, 2002 dalam Firmansyah, 2000)

Notasi yangg digunakan dalam ARIMA adalah notasi yang mudah dan umum. Misalkan model ARIMA $(0,1,1)(0,1,1)^{12}$ dijabarkan sebagai berikut:

$$
(1-B)\left(1-B^{12}\right) X_{t}=\left(1-\theta_{1} B\right)\left(1-\theta_{1} B^{12}\right) e_{t}
$$

Dimana :

$$
\begin{array}{ll}
(1-B) & =\text { Pembeda pertama yang tidak musiman (nonseasonal) } \\
\left(1-B^{12}\right) & =\text { Pembeda pertama yang musiman (seasonal) } \\
\left(1-\theta_{1} B\right) & =\text { MA }(1) \text { yang tidak musiman } \\
\left(1-\theta_{1} B^{12}\right) & =\text { MA }(1) \text { yang musiman }
\end{array}
$$

Penjabaran dari persamaan tersebuat mwnjadikannya sebuah persamaan regresi yang lebih umum. Untuk model diatas bentuknya adalah:

$$
X_{t}=X_{t-1}+X_{t-2}-X_{t-3}+e_{t}-\theta_{1} e_{t-1}-\emptyset_{1} e_{t-12}+\emptyset_{1} e_{t-13}
$$

Untuk meramalkan suatu periode ke depan, yaitu $X_{t}+1$ maka seperti pada persamaan berikut:

$$
X_{t}+1=X_{t}+X_{t-11}-X_{t-12}+e_{t+1}-\theta_{1} e_{t}-\emptyset_{1} e_{t-11}+\emptyset_{1} e_{t-12}
$$

Nilai $e_{t+1}$ tidak akan diketahui, karena nilai yang diharapkan untuk kesalahan random pada masa yang akan datang harus ditetapkan sama dengan nol. Akan tetapi dari model yang disesuaikan (fitted model) kita boleh mengganti nilai $e_{t}, e_{t-11}$ dan $e_{t-12}$ dengan nilai mereka yang ditetapkan secara empiris (seperti yang diperbolehkaan setelah iterasi terakhir Algoritma Marquardt). Tentu saja bila kita meramalkan jauh ke depan, tidak akan kita peroleh nilai empires untuk "e" sesudah beberapa waktu, dan oleh sebab itu nilai harapan mereka akan seluruhnya nol. Untuk nilai X, pada awal proses peramalan, kita akan mengetahui nilai $e_{t}, e_{t-11}$ dan $e_{t-12}$. Akan tetapi sesudah beberapa saat, niali $\mathrm{X}$ akan berupa nilai ramalan (forecasted value), bukan nilai-nilai masa lalu yang telah kita ketahui. 


\section{STATMAT}

(Jurnal Statistika dan Matematika)

\subsection{Definisi Penjualan}

Perusahaan dalam pemasaran produk hasil produksinya mempergunakan konsep penjualan (selling concept), yang menyatakan bahwa konsumen tidak akan membeli cukup banyak produk perusahaan, kecuali jika perusahaan tersebut melakukan usaha penjualan dengan promosi dalam skala besar. Dalam transaksi jual beli, konsumen selain membeli untuk memenuhi kebutuhan juga karena tertarik dari segi promosi perusahaan tersebut.

Konsep menjual menyatakan bahwa konsumen jika diabaikan, biasanya tidak akan membeli produk organisasi dalam jumlah yang cukup banyak. Karena itu, organisasi harus melakukan usaha penjualan dan promosi yang agresif. Kebanyakan perusahaan mempraktikkan konsep penjualan ketika mereka kelebiham kapasitas produk. Sehingga tujuan mereka adalah untuk menjual apa yang mereka buat dan bukan membuat apa yang diinginkan pasar, pemasaran seperti ini beresiko tinggi. Konsep pemasaran ini berfokus pada penciptaan transaksi penjualan dan bukannya membangun hubungan jangka panjang dan menguntungkan dengan pelanggan. Konsep ini berasumsi bahwa pelanggan yang terbujuk membeli produknya akan menyukainya. Atau, jika mereka tidak suka, mereka mungkin akan melupakan kekecewaan mereka dan membelinya lagi di lain waktu. Asumsi-asumsi mengenai pelanggan ini sangat keliru. Kebanyakan peneliti menunjukkan bahwa pelanggan yang tidak puas tidak akan pernah membeli lagi. Celakanya lagi, apabila pelanggan yang puas rata-rata menceritakan pengalaman baiknya kepada tiga orang, pelanggan yang tidak puas menceritakan pengalaman buruknya kepada sepuluh orang lain. Karena pada dasarnya konsep pemasaran menyatakan bahwa kunci untuk meraih tujuan organisasi adalah menjadi lebih efektif dari pada para pesaing dalam memadukan kegiatan pemasaran guna menetapkan dan memuaskan kebutuhan dan keinginan pasar sasaran .

Penjualan merupakan bagian dari kegiatan ekonomi yang biasa dilakukan oleh semua orang. Dalam penjualan produk sebuah perusahaan dengan promosi yang baik dan menejemen yang baik akan memperoleh laba yang baik pula dari hasil penjualan tersebut, dimana hasil penjualan telah dapat menutup dari biaya produksi. Terdapat beberapa definisi tentang penjualan antara lain :

a. Penjualan adalah interaksi antara individu saling betemu muka yang ditujukan untuk menciptakan memperbaiki, menguasai atau mempertahanklan hubungan pertukaran yang saling menguntungkan dengan pihak lain.

b. Penjualan adalah proses dimana sang penjual memastikan mengaktivasikan dan membutuhkan atas keinginan pembeli agar dapat dicapai manfaat bagi penjual maupun pembeli yang berkelanjutan dan yang menguntungkan kedua belah pihak.

Berdasarkan definsi-definisi diatas maka dapat kita simpulkan bahwa penjualan adalah usaha yang dilakukan manusia untuk menyampaikan barang kebutuhan yang telah dihasilkannya kepada mereka yang memerlukannya dengan imbalan uang 


\section{STATMAT}

(Jurnal Statistika dan Matematika)

menurut harga yang ditentukan atas persetujuan bersama. Dari kesimpulan diatas dapat kita ketahui bahwa penjualan sangatlah penting bagi sebuah perusahaan karena penjualan dapat menentukan bertahannya sebuah perusahaan atau tidak. Dalam hal ini Kopkar Al-Zahra Indonesia juga sangat tergantung pada sebuah penjualan seragam sekolahnya, maka untuk mengetahui tingkat penjualan pada bulan, tahun yang akan datang perlu kita lakukan peramalan guna memprediksikan berapa tingkat penjualan pada masa yang akan datang, sehingga dengan mempergunakan hasil peramalan tersebut perusahaan dapat mengetahui jumlah produksi yang harus dilakukan oleh perusahaan tersebut pada masa yang akan datang.

\subsubsection{Jenis-jenis Penjualan}

Ada beberapa jenis penjualan yaitu Trade Selling, Technical Selling, Missioary Selling, dan New Business Selling.

1) Trade Selling

Trade Selling adalah suatu jenis penjualan yang dilakukan oleh wiraniaga kepada grosir-grosir, dengan tujuan untuk dijual kembali.

2) Technical Selling

Technical Selling adalah berusaha meningkatkan penjualan dengan pemberian saran dan nasehat kepada pembeli atau konsumen akhir dari barang dan jasanya. Dalam hal yang satu ini wirausaha tersebut memiliki tugas utama untuk mengidentifikasi dan juga menganalisis berbagai permasalahan yang dihadapi para pembeli lalu kemudian serta menunjukkan bagaimana produk/jasa yang ditawarkan dapat mengatasi masalah si pembeli/konsumen.

3) Missioary Selling

Missioary Selling dalam hal yang satu ini wirausaha berusaha meningkatkan penjualan serta dengan mendorong pembeli yang tentunya untuk membeli produk atau jasa dari penyalur perusahaan, dalam hal ini perusahaan tersebut atau yang bersangkutan mempunyai penyalur tersendiri dalam pendistribusian produknya atau jasanya.

4) New Business Selling

New Business Selling adalah berusaha membuka transaksi-transaksi baru dengan cara mengubah calon konsumen menjadi konsumen.

\subsubsection{Tujuan Penjualan}

Sesuai dengan konsep penjualan (selling concept) bahwa perusahaan dalam melakukan penjualan haruslah menggunakan promosi yang besar-besaran agar menarik minat konsumen. Sehingga penjualan sangatlah penting dalam sebuah perusahaan.

Adapun tujuan umum dalam penjualan adalah mencapai volume penjualan tertentu, mendapatkan laba yang banyak dan meningkatkan produksi. 
STATMAT

(Jurnal Statistika dan Matematika)

\subsection{Metode Penelitian}

Metodologi yang dilakukan penulis ada 2,yaitu

1) Studi kepustakaan

Proses pengumpulan informasi dan metode dengan cara mencari dan membaca buku,dan sumber data yang tersedia di perpustakaan,serta melalui internet yang berkaitan dengan peramalan.

2) Metode perancangan

Penulis merancang suatu program aplikasi yang dgunakan untuk meramalkan volume penjualan dengan menggunakan metode Autoregressive Integrated Moving Average (ARIMA).

\subsection{Metode Penentuan Sampel}

Sampel adalah sebagian atau wakil populasi yang akan diteliti (Arikunto, 2002:109). Menurut Sugiyono sampel adalah bagian atau jumlah dan karakteritik yang dimiliki oleh populasi tersebut. Bila populasi besar, dan peneliti tidak mungkin mempelajari semua yang ada pada populasi, missal karena keterbatan dana, tenaga dan waktu, maka peneliti akan mengambil sampel dari populasi itu. Apa yang dipelajari dari sampel itu, kesimpulannya akan diberlakukan untuk populasi. Untuk itu sampel yang diambil dari populasi harus betul-betul representative (Sugiyono,2016:215).

Sampel penelitian ini adalah Data jumlah penjualan seragam sekolah Kopkar Al-Zahra Indonesia dari bulan Juli 2016 sampai bulan Juli 2018.

\subsection{Metode Pengolahan Data}

Berikut adalah lankah-langkah melakukan analisis data dengan model ARIMA adalah sebagai berikut:

1. Identifikasi

a. Berdasarkan plot data aktual dapat diketahui apakah data sudah stasioner. Jika belum stasioner maka data harus distasionerkan terlebih dahulu.

b. Tentukan kombinasi model ARIMA yang mungkin. Dari plot autokorelasi tentukan ordo MA (q), dari plot autokorelasi parsial tentukan ordo AR (p).

2. Estimasi dan pengujian model ARIMA yang mungkin, serta pemilihan model terbaik.

3. Tentukan persamaan dan nilai ramalan model ARIMA terbaik.

\section{HASIL DAN PEMBAHASAN}

\subsection{Data Penelitian}

Data yang digunakan adalah data jumlah penjualan seragam sekolah Kopkar Al-Zahra Indonesia pada bulan Januari 2016 sampai bulan Juli 2018. Adapun tabel yang disajikan adalah sebagai berikut: 
(Jurnal Statistika dan Matematika)

Tabel 1. Penjualan Seragam Sekolah Kopkar Al-Zahra Indonesia.

\begin{tabular}{|c|c|c|}
\hline Tahun & Bulan & $\begin{array}{c}\text { Jumlah } \\
\text { Penjualan }\end{array}$ \\
\hline \multirow{12}{*}{2016} & Januari & 68 \\
\hline & Februari & 51 \\
\hline & Maret & 64 \\
\hline & April & 266 \\
\hline & Mei & 676 \\
\hline & Juni & 537 \\
\hline & Juli & 189 \\
\hline & Agustus & 230 \\
\hline & September & 142 \\
\hline & Oktober & 164 \\
\hline & November & 118 \\
\hline & Desember & 182 \\
\hline \multirow{12}{*}{2017} & Januari & 82 \\
\hline & Februari & 48 \\
\hline & Maret & 61 \\
\hline & April & 257 \\
\hline & Mei & 678 \\
\hline & Juni & 656 \\
\hline & Juli & 175 \\
\hline & Agustus & 237 \\
\hline & September & 165 \\
\hline & Oktober & 120 \\
\hline & November & 92 \\
\hline & Desember & 129 \\
\hline \multirow{3}{*}{2018} & Januari & 87 \\
\hline & Februari & 95 \\
\hline & Maret & 108 \\
\hline \multirow{4}{*}{2018} & April & 234 \\
\hline & Mei & 598 \\
\hline & Juni & 620 \\
\hline & Juli & 649 \\
\hline
\end{tabular}

\subsection{Diagnostik Model ARIMA}

Pemeriksaan diagnostik dengan menggunakan uji hipotesis dengan uji LjungBox yitu sebagi berikut:

1) $\operatorname{ARIMA}(1,1,1)$

Perhitungan nilai $r_{k}$ dari model ARIMA $(1,1,1)$ untuk uji Ljung-Box adalah sebagai berikut:

a. Hipotesis: 


$$
H_{0}:-0,039=\ldots=-0,034=0 \quad \text { (bersifat random) }
$$

$H_{1}:-0,034 \neq 0$

(tidak bersifat random)

b. Statistik Uji:

$$
\begin{aligned}
Q & =n(n+2) \sum_{n}^{m} \frac{r_{k}^{2}}{(n-k)} \\
& =31(31+2) * 0,022404967 \\
& =22,92 \\
X^{2} & (0,05 ; 14)=23,684
\end{aligned}
$$

c. Kriteria Pengujian:

$22,92 \leq 23,684$, berarti terima $H_{0}$ maka nilai error bersifat random dan model dapat diterima.

2) $\operatorname{ARIMA}(1,1,0)$

Perhitungan uji Ljung-Box adalah sebagai berikut:

a. Hipotesis:

$$
\begin{array}{lr}
H_{0}: 0,0548=\ldots=-0,011=0 & \text { (bersifat random) } \\
H_{1}:-0,011 \neq 0 & \text { (tidak bersifat random) }
\end{array}
$$

b. Statistik Uji:

$$
\begin{aligned}
Q & =n(n+2) \sum_{n}^{m} \frac{r_{k}^{2}}{(n-k)} \\
& =31(31+2) * 0,029766537 \\
& =30,451 \\
X^{2} & (0,05 ; 14)=23,684
\end{aligned}
$$

c. Kriteria Pengujian:

$30,451 \geq 23,684$, berarti tolak $H_{0}$ maka nilai error tidak bersifat random dan model tidak dapat diterima.

3) $\operatorname{ARIMA}(0,1,1)$

Perhitungan uji Ljung-Box adalah sebagai berikut:

a. Hipotesis:

$$
\left.H_{0}:-0,066=\ldots=-0,018=0 \quad \text { (bersifat random }\right)
$$




\section{STATMAT}

(Jurnal Statistika dan Matematika)

$$
H_{1}:-0,018 \neq 0
$$

(tidak bersifat random)

b. Statistik Uji:

$$
\begin{aligned}
Q= & n(n+2) \sum_{n}^{m} \frac{r_{k}^{2}}{(n-k)} \\
= & 31(31+2) * 0,024494868 \\
& =25.058 \\
X^{2} & (0,05 ; 14)=23,684
\end{aligned}
$$

c. Kriteria Pengujian:

25,058 $\geq 23,684$, berarti tolak $H_{0}$ maka nilai error tidak bersifat random dan model tidak dapat diterima.

\subsection{Pemilihan Model ARIMA}

Dari pemeriksaan diagnostik didapatkan model ARIMA yang diterima untuk peramalan yaitu ARIMA $(1,1,1)$. Maka peramalan selanjutnya menggunakan ARIMA $(1,1,1)$ dengan persamaan:

$$
(1-B)\left(1-\emptyset_{1} B\right) X_{t}=\mu^{\prime}+\left(1-\theta_{1} B\right) e_{t}
$$

Atau

$$
\begin{gathered}
X_{t}=\mu^{\prime}+e_{t}-\theta_{1} e_{t-1}+X_{t-1}+\emptyset_{1} X_{t-1}-\emptyset_{1} X_{t-2} \\
X_{t}=19,876+e_{t}-(-0,645) e_{t-1}+X_{t-1}+(-0,369) X_{t-1}-(-0,369) X_{t-2}
\end{gathered}
$$

Peramalan dari bulan Agustus sampai bualan Desember Tahun 2018 dengan SPSS 22 adalah sebagai berikut:

Tabel 2. Hasil Output SPSS Peramalan Bulan Agustus sampai Bulan Bulan Desember Tahun 2018

\begin{tabular}{|c|r|r|r|}
\hline \multirow{3}{*}{ Periode } & \multicolumn{3}{|c|}{ Forcast } \\
\cline { 2 - 4 } & \multicolumn{3}{|c|}{ jumlah penjualan-Model_1 } \\
\cline { 2 - 4 } & Forecast & UCL & \multicolumn{1}{c|}{ LCL } \\
\hline Agt-18 & 700,3 & 1073,8 & 326,8 \\
\hline Sep-18 & 708,6 & 1314 & 103,1 \\
\hline Okt-18 & 732,7 & 1480,3 & $-14,9$ \\
\hline Nov-18 & 751 & 1624,9 & $-122,9$ \\
\hline Des-18 & 771,5 & 1753,2 & $-210,3$ \\
\hline
\end{tabular}




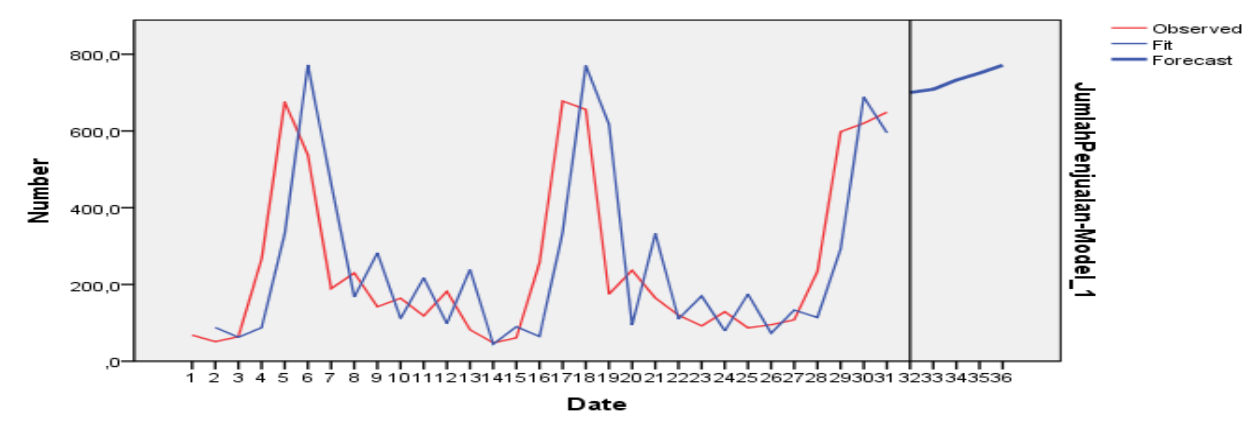

Gambar 2. Peramalan Bulan Agustus sampai dengan Bulan Desember Tahun 2018 dengan Model ARIMA $(1,1,1)$

\subsection{Pembahasan}

Berdasarkan hasil pembahasan sebelumnya, didapatkan penjelasan yang lebih rinci sebagai berikut:

1. Metode yang tepat untuk data penjualan seragam sekolah Kopkar Al-Zahra Indonesia adalah metode ARIMA (Autoregressive Integrated Moving Average). Karena paada Gambar 4.1 pola data yang terbentuk adalah pola data musiman.

2. Pada Gambar 4.1, Gambar 4.2 dan Gambar 4.3 nilai-nilai aktual pada plot data asli jauh dari garis linier dan adanya suatu trend sehingga data tersebut dapat dikatakan belum stasioner, maka diperlukan pembedaan (differencing) pertama untuk menstasionerkan data tersebut.

3. Model yang didapatkan dari pemeriksaan diagnostik dengan uji Ljung-Box adalah model ARIMA $(1,1,1)$ dengan persamaan sebagai berikut: $X_{t}=19,876+e_{t}-(-0,645) e_{t-1}+X_{t-1}+(-0,369) X_{t-1}-(-0,369) X_{t-2}$

4. Hasil dari permalan menggunakan metode ARIMA $(1,1,1)$ yaitu jumlah penjualan seragam sekolah Kopkar Sekolah Al-Zahra Indonesia untuk 5 periode berikutnya adalah pada bulan Agustus 2018 sebanyak 700,3 buah seragam, bulan September 2018 sebanyak 708,6 buah seragam, bulan Oktober 2018 sebanyak 732,7 buah seragam, bulan November sebanyak 751 buah seragam, dan bulan Desember 2018 sebanyak 771,5 buah seragam.

\section{SIMPULAN DAN SARAN}

\subsection{Kesimpulan}

Berdasarkan hasil penelitian dan pembahasan yang telah dilakukan dapat disimpulkan bahwa:

1. Metode ARIMA (Autoreggressive Integrated Moving Average) dapat digunakan untuk meramalkan penjualan seragam sekolah Kopkar Al-Zahra Indonesia karena data penjualan seragam sekolah tersebut membentuk data musiman, sehingga metode yang tepat adalah metode ARIMA.

2. Diperoleh bentuk persamaan dengan model ARIMA $(1,1,1)$ sebagai berikut:

$$
X_{t}=19,876+e_{t}-(-0,645) e_{t-1}+X_{t-1}+(-0,369) X_{t-1}-(-0,369) X_{t-2}
$$




\section{STATMAT}

(Jurnal Statistika dan Matematika)

3. Hasil prediksi jumlah penjualan seragam sekolah Kopkar Sekolah Al-Zahra Indonesia untuk 5 periode berikutnya adalah pada bulan Agustus 2018 sebanyak 700,3 buah seragam, bulan September 2018 sebanyak 708,6 buah seragam, bulan Oktober 2018 sebanyak 732,7 buah seragam, bulan November sebanyak 751 buah seragam, dan bulan Desember 2018 sebanyak 771,5 buah seragam.

\subsection{Saran}

Dari hasil penelitian yang telah dilakukan, peneliti menyarankan beberapa hal sebagai berikut:

1. Kepada Kopkar Sekolah Al-Zahra Indonesia yang ingin mengetahui banyaknya penjualan seragam sekolah pada bulan berikutnya dapat menggunakan metode ARIMA

2. Untuk menghadapi peningkatan penjualan seragam sekolah, pihak Kopkar AlZahra Indonesia harus lebih meningkatkan kualitasnya dari segi manapun, khususnya dalam ketersediaan stok seragam sekolah.

3. Dalam membuat laporan, penulis harus benar-benar memahami materi maupun aplikasi yang akan digunakan pada laporan penelitian selanjutnya, agar tidak terjadi kesalahan dalam mengaplikasikan data serta hasilnya.

\section{DAFTAR PUSTAKA}

Djauhari, Manan. 2004. Metode Peramalan. Jakarta: Pusat Penerbitan Universitas Terbuka

Ekonomi. 2014. Koperasi $\quad$ Sekolah. From http://ekonomisku.blogspot.com/2015/02/koperasi-sekolah.html?m=1 (diakses pada 20 Juli 2018)

Makridakis, Spyros., Steven C. Wheelwright, dan Victor E. McGee. 1999. Metode dan Aplikasi Peramalan jilid I. Terj. Ir Hari Suminto. Jakarta: Binapura Aksara.

Sahayu, Dra. Wening.___ Teori Metodologi Penelitian. From http://staff.uny.ac.id/sites/default/files/pendidikan/dra-wening-sahayu$\mathrm{mpd} /$ metodologi-penelitian-pdf, (diakses pada 13 Juli 2018)

Soejoeti, Z. 1987. Analisis Runtut Waktu. Jakarta: Universitas Terbuka.

Subagyo, Pangestu. 1986. Forecasting Konsep dan Aplikasi. Yogyakarta: BPFE UGM Yogyakarta.

Sugiyono., 2016. Metode Penelitian Kuantitatif, Kualitatif, dan R\&D. AFABETA, cv, Bandung.

Syahputra, Irvandi. M. Isa Irawatn, dan Nuri Wahyuningsih. 2015. Aplikasi Algoritma Memetika untuk Peramalan Kurs Valuta Asing dengan Menggunakan Model ARIMA

(Box-Jenkins).

From http://ejurnal.its.ac.id/index.php/sains_seni/article/download/12359/31245-1 . (diakses pada 20 Agustus 2018) 